\title{
PENGARUH UKURAN PERUSAHAAN, AUDIT TENURE, KUALITAS AUDIT, DAN AUDIT REPORT LAG TERHADAP OPINI AUDIT GOING CONCERN
}

\author{
Shulasi Nur Haalisa*, Nur Isna Inayati
}

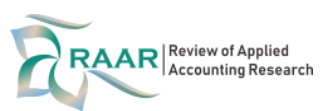

Affiliation:

Accounting Department, Universitas Muhammadiyah Purwokerto, Indonesia

*Correspondence:

haalisashulasi@gmail.com

Article Process:

Submitted:

December 26, 2020

Reviewed:

January 10, 2021

Revised:

February 15, 2021

Accepted:

February 24, 2021

Published:

February 28, 2021

Citation:

Haalisa, S. N., \& Inayati, N. I. (2021). Pengaruh Ukuran Perusahaan, Audit Tenure, Kualitas Audit, Dan Audit Report Lag Terhadap Opini Audit Going Concern. Review of Applied Accounting Research, 2(2), 25-36.

Office Address:

Jl. K.H. Ahmad Dahlan, Dukuhwaluh, Kec.

Kembaran, Kabupaten

Banyumas, Jawa Tengah 53182

e-ISSN : 2807-8969

\begin{abstract}
ABSTRAK
Penelitian ini bertujuan untuk menganalisis pengaruh ukuran perusahaan, masa audit, kualitas audit dan audit report lag terhadap opini audit going concern. Penelitian ini merupakan penelitian kuantitatif. Sumber data yang digunakan adalah data sekunder berupa laporan keuangan tahunan perusahaan. Dalam penelitian ini, going concern dan kualitas audit dihitung dengan menggunakan dummy. Populasi yang digunakan dalam penelitian ini adalah perusahaan pertambangan yang terdaftar di Bursa Efek Indonesia tahun 2015 sampai dengan tahun 2019. Pengambilan sampel dilakukan dengan metode teknik purposive sampling dan diperoleh 29 dari 145 data observasi. Hasil penelitian ini menunjukkan bahwa ukuran perusahaan dan masa audit tidak berpengaruh terhadap opini audit going concern. Sedangkan audit report lag dan kualitas audit berpengaruh terhadap opini going concern.
\end{abstract}

Kata kunci: kualitas audit, tenur audit, kualitas audit, audit report lag, opini audit going concern

\begin{abstract}
This study aims to analyze the effect of company size, audit tenure, audit quality and audit report lag on going concern audit opinion. This research is a quantitative research. The data source used is secondary data in the form of the company's annual financial statements. In this study, going concern and audit quality are calculated using a dummy. The population used in this study is mining companies listed on the Indonesia Stock Exchange from 2015 to 2019. Sampling was carried out by purposive sampling technique method and obtained 29 as 145 observed data. The results of this study show that company size, and audit tenure have no effect on going concern audit opinion. While audit report lag and audit quality heve efeect on going concern opinion.
\end{abstract}

Keywords : audit quality, audit tenure, audit quality, audit report lag, going concern audit opinion 


\section{PENDAHULUAN}

Perusahaan yang baik perlu menyampaikan laporan keuangan sebagai bentuk pertanggungjawaban terhadap publik atas kegiatan oprasioanlnya(Sufiana \& Karina, 2020). Laporan keuangan merupakan sarana utama bagi perusahaan untuk menginformasikan kondisi perusahaan kepada pihak internal dan eksternal perusahaan, dalam Statement of Financial Accounting Concepts (SFAC) No.1 dijelaskan bahwa tujuan utama dari laporan keuangan adalah untuk memberikan informasi yang berguna dalam pengambilan keputusan bisnis dan ekonomi. Laporan keuangan menjadi cerminan kondisi ekonomi perusahaan apakah dapat melanjutkan kelangsungan usaha perusahaan atau sebaliknya. Going concern merupakan istilah yang mengasumsikan apakah perusahaan dapat meneruskan kegiatan bisnisnya di masa mendatang. Auditor melakukan evaluasi terhadap kemampuan perusahaan dalam mewujudkan rencana, tanggung jawab dan kegiatan usaha dalam jangka waktu panjang sebagai tolak ukur going concern. Dengan demikian penelitian going concern menjadi masalah mendasar di perusahaan, sehingga perlu menentukan faktor yang menjadi penyebab munculnya opini audit going concern, agar bisa dijadikan acuan perusahaan dalam menghadapi keadaan perekonomian yang fluktuatif, sehingga opini going concern tetap dapat diprediksi (Istiana, 2010).

\section{Tujuan dan Manfaat Penelitian}

1. Untuk mendapatkan bukti empiris pengaruh negatif ukuran perusahaan terhadap opini audit going concern pada perusahaan Pertambangan yang terdaftar di BEI tahun 2015-2019?

2. Untuk mendapatkan bukti empiris pengaruh negatif audit tenure terhadap opini audit going concern pada perusahaan Pertambangan yang terdaftar di BEI tahun 2015-2019?

3. Untuk mendapatkan bukti empiris pengaruh positif kualitas audit terhadap opini audit going pada perusahaan Pertambangan yang terdaftar di BEI tahun 2015-2019?

4. Untuk mendapatkan bukti empiris pengaruh positif audit report lag terhadap opini audit going concern pada perusahaan Pertambangan yang terdaftar di BEI tahun 2015-2019?

\section{TINJAUAN PUSTAKA DAN RUMUSAN HIPOTESIS}

\section{Teori Agensi}

Penelitian ini menggunakan teori agensi yang menjelaskan hubungan anatara prinsipal (stakeholders) dan agen (manajemen) (Syahputra \& Yahya, 2017). Dalam penelitian lain menyebutkan pengertian teori agensi adalah gambaran mengenai suatu hubungan agen sebagai suatu kotrak dibawah satu prinsipal, baik agen maupun prinsipal diasumsikan memiliki rasionalisasiekonomi (Kusumaningrum, 2019).

Maksud dari hubungan agen sebagai suatukontrak adalah pihak manajemen dikontrak oleh pemegang saham untuk bekerja demi kepentingan pemegang saham (Anita, 2017). Namun dalam praktiknya hubungan atara prinsipal dan agen akan menimbulkan masalah akibat adanya kepentingan yang saling bertentangan (Syahputra \& Yahya, 2017).

\section{Auditing}

Pengertian auditing secara umum adalah suatu proses yang sistematis yang bertujuan untuk memperoleh bukti dan mengevaluasi bukti tersebut secara obyektif mengenai kegiatan dan kejadian ekonomi dan dimaksudkan untuk menetapkan kesesuaian dengan kriteria yang telah ditetapkan, kemudian melaporkan hasilnya dalam bentuk laporan audit serta 
digunakan oleh pihak yang berkepentingan (Pemegang saham, Manajemen, Kreditur dan Investor).

\section{Opini Audit}

Opini audit (audit opinion) adalah pendapat auditor tentang laporan keuangan yang telah diauditnya. opini audit dibedakan menjadi modified opinion dan unmodified opinion. Menurut standar profesional akuntan publik SA Seksi 110, tujuan audit atas laporan keuangan oleh auditor independen pada umumnya adalah untuk menyatakan pendapat tentang kewajaran dalam semua hal yangmaterial, posisi keuangan, hasil usaha, perubahan ekuitas, dan arus kas sesuai dengan prinsip akuntansi yang berlaku umum di Indonesia (Qolillah, 2016).

\section{Going Concern}

Opini audit going concern merupakan opini yang dikeluarkan auditor berkaitan dengan kemampuan perusahaan dalam mempertahankan kelangsungan hidupnya (Mutsanna \& Sukirno, 2020). Going concern dapat dikatakan sebagai pendapat atau asumsi mengenai kemungkinan perusahaan tersebut mampu bertahan minimal 5 tahun kedepan (Hati \& Rosini, 2017).

\section{Ukuran Perusahaan}

Ukuran perusahaan menggambarkan besar kecilnya perusahaan yang dapat di tunjukan dengan total aktiva, jadi ukuran perusahaan yaitu besarnya total aset yang dimiliki perusahaan secara umum (Melania et al., 2019). Total aset perusahaan menggambarkan kekayaan yang dimiliki perusahaan untuk menunjang kegiatan operasinya, nilai penjualan menggambarkan perputaran uang yang dapat dihasilkan perusahaan, dan ekspansi pasar yang dapat memeberi gambaran seberapa besar perusahaan dikenal oleh masyarakat (Mutsanna \& Sukirno, 2020).

\section{Audit Tenure}

Audit Tenure dalam penelitian ini merupakan lama hubungan KAP dengan perusahaan. Audit tenure diukur dengan menghitung jangka waktu (bulan/tahun)dimana KAP yang sama telah melakukan perikatan audit (Andyny, 2017). Audit Tenure dapat berdampak pada kinerja auditor dampak yang ditimbulkan seperti, hubungan emosional antara uditor dan klien. Hal tersebut dapat mempengaruhi hasil opini audit yang di keluarkan oleh auditor (Yanuariska \& Ardiati, 2018).

\section{Kualitas Audit}

Kualitas audit didefinisikan sebagai probabilitas dimana seorang auditor menemukan dan melaporkan adanya suatu sistem akuntansi kliennya. KAP yang baik akan selalu berusaha menyajikan kualitas audit yang bagus karena berhubungan erat dengan reputasi yang dimiliki oleh KAP tersebut (Kartika et al., 2012).

RAAR

Vol.1 No.1

\section{Audit Report lag}

Audit Report lag merupakan jumlah hari yang yang digunakan untuk menyelesaikan laporan keuangan (Syahputra \& Yahya, 2017). Auditor haruslah bersikap teliti terhadap pemeriksaan laporan keuangan untuk menghindari kesalahan dalam proses audit, hal tersebut mengakibatkan proses audit laporan keuangan mejadi lebih lama (Harjito, 2017). Rentang waktu penyelesaian audit laporan keuangan dihitung dari mulainya tutup buku sampai laporan keuangan tersebut diterbitkan (Sari, 2020). 


\section{HIPOTESIS PENELITIAN}

Pengaruh ukuran perusahaan terhadap opini audit going concern

Ukuran perusahaan merupakan ukuran besar kecilnya sebuah perusahaan yang ditunjukan atau dinilai dari total aset, jumlah laba, beban pajak dan lain lain (Hamdani, 2019). Apabila perusahaan tergolong dalam perusahaan yang kecil namun, memiliki manajemen kinerja yang bagus maka perusahaan dianggap mampu bertahan hidup dalam jangka panjang sehingga semakin kecil potensi mendapatkan opini audit going concern (Chandra et al., 2019).

$\mathbf{H}_{1}$ : Ukuran perusahaan berpengaruh negatif terhadap opini audit going concern

\section{Pengaruh audit tenure terhadap opini audit going concern}

Audit tenure merupakan jangka waktu kerja sama yang terjalin antara KAP dengan auditee yang sama. Dalam penelitian Syahputra \& Yahya (2017) audit tenure diukur dengan menghitung tahun dimana KAP yang sama telah melalukan perikatan dengan klien.

Dalam penelitian Yanuariska \& Ardiati (2018) disimpulkan bahwa audit tenure berpengaruh negatif terhadap opini audit going concern karena semakin lamanya hubungan yang terjalin antara KAP dan klien akan mempengaruhi tingkat independensi auditor sehingga kemungkinan pemberian opini audit going concern akan semakin kecil. Sejalan dengan penelitian Vernando \& Yuniarto (2018) yang menyatakan bahwa perusahaan yang memiliki masa perikatan dengan KAP yang semakin lama akan memilki probabilitas yang lebih kecil untuk menerima opini audit going concern.

$\mathbf{H}_{2}$ : Audit tenure berpengaruh positif terhadap opini audit going concern

\section{Pengaruh kualitas audit terhadap opini audit going concern}

Kualitas Audit adalah segala kemungkinan yang terjadi saat auditor memeriksa laporan keuangan perusahaan. Dalam penelitian Oktaviani \& E (2020) kualitas audit berpengaruh positif terhadap penerimaan opini audit going concern, dengan demikian dapat diartikan bahwa KAP big fourmenghasilkan kualitas audit yang lebih baik dan cenderung lebih berani dalam memberikan opini audit going concern. Hasil penelitian lain juga mengahasilkan pengaruh positif kualitas audit terhadap penerimaan audit going concern(Sufiana \& Karina, 2020).

$\mathbf{H}_{3}$ : Kualitas Audit berpengaruh positif terhadap opini audit going concern

\section{Pengaruh audit report lag terhadap opini audit going concern}

Audit report lag dapat di artikan sebagai rentang waktu yang digunakan untuk menyelesaikan audit laporan keuangan, yang diukur dari lamanya hari yang dibutuhkan untuk memperoleh laporan auditor, lamanya waktu dihitung sejakawal tutup buku sampai tanggal yang tertera pada saat diterbitkanya laporankeuangan (Sari, 2020)

RAAR

Vol.1 No.1 
Audit report lag yang panjang mengindikasikan perusahaan tersebut mengalami permasalahan sehingga, audit report lag berpengaruh negatif terhadap opini audit going concern. Sejalan dengan penelitian yang dilakukan oleh Anita (2017).

$\mathbf{H}_{4}$ : Audit report lag berpengaruh positif terhadap opini audit going concern

\section{METODOLOGI PENELITIAN}

Populasi pada penelitian ini adalah seluruh perusahaan-perusahan Pertambangan yang terdaftar di Bursa Efek Indonesia mulai tahun 2015 - 2019. Sampel dalam penelitian ini adalah 37 perusahaan pertambangan yang tedaftar di Bursa Efek Indonesia tahun 2015 2019.

Tabel 1. Tahapan Seleksi Sampel

\begin{tabular}{c|l|c}
\hline No & \multicolumn{1}{|c|}{ Kriteria } & Jumlah \\
\hline 1. & $\begin{array}{l}\text { Perusahaan Pertambangan yang terdaftar di BEI tahun 2015- } \\
2019\end{array}$ & 47 \\
\hline $\begin{array}{l}\text { Jumlah perusahaan pertambangan yang data laporan } \\
\text { keuangannya ditemukan secara tidak berturut-turut selama } \\
\text { periode 2015-2019 }\end{array}$ & $(10)$ \\
\hline Perusahaan yang menjadi sampel & $\mathbf{3 7}$ \\
\hline Tahun pengamatan 2015-2019 & $\mathbf{5}$ \\
\hline Total sampel periode penelitian
\end{tabular}

\section{Variabel Dependen (Y)}

Pengukuran dilakukan dengan dummy dimana akan ada nilai 1 untuk perusahaan yang menerima opini audit going concern dan nilai 0 untuk perusahaan yang menerima opini audit non going concern

\section{Variabel Independen $(\mathbf{X})$}

A. Ukuran perusahaan merupakan ukuran besar kecilnya sebuah perusahaan yang ditunjukan atau dinilai dari total aset, jumlah laba, beban pajak dan lain lain (Hamdani, 2019). Kemudian ukuran perusahaan dapat diukur dengan besarnya total aset yang dimiliki perusahaan tersebut (Minerva et al., 2020). Indikator yang digunakan.

$$
\text { SIZE = In (total aset) }
$$

B. Audite tenure di ukur menggunakan skala interval disesuaikan dengan lamanya hubungan KAP dengan klien, tahun perikatan dimulai dengan angka satu dan ditambah dengansatu untuk tahun tahun berikutnya (Fahmi, 2016).

C. Kualitas Audit variabel ini dihitung menggunakan variabel dummy dimana afiliasi KAP dalam kategori big four akan diberi kode 1 dan kategori non big four akan 
diberi kode 0

D. Audit Report Lag dihitung dengan menggunakan jumlah hari antara akhir periode akuntansi sampai dikeluarkannya laporan audit. Selain itu audit report lag menggunakan indikator tanggal laporan audit dikurangi tanggal laporan keuangan dengan skala nominal (Minerva et al., 2020)

ARL = tanggal laporan audit - tanggal laporan keuangan tahunan

\section{Analisis Regresi Logistik}

Regresi logistik adalah regresi yang digunakan untuk menguji apakah probabilitas terjadinya variabel terikat dapat diprediksi dengan variabel bebasnya (Ghozali, 2016). Dalam penelitian ini analisis regresi logistik digunakan apabila variabel bebasnya merupakan kombinasi antara metric dan non matric (nominal). Sehingga tidak memerlukan lagi uji normalitas dan uji asumsiklasikpada variabel bebas (Ghozali, 2016). Adapun model regresi yang digunakan dalam pengujian hipotesis adalah sebagai berikut.

Persamaan model logistic regression

Keterangan :

$$
\begin{array}{ll}
\operatorname{Ln} \frac{p}{1-p} & =\text { dummy }(1: \text { ODC; } 0: \text { non OGC }) \\
\alpha & =\text { Konstanta } \\
\beta 1, \beta 2, \beta 3, \beta 4 & =\text { Koefisien regresi } \\
U P & =\text { Ukuran Perusahaan } \\
A T & =\text { Audite Tenure } \\
K A & =\text { Kualitas Audit } \\
A R L & =\text { Audit Report Lag } \\
e & =\text { Standar Error }
\end{array}
$$

\section{HASIL DAN PEMBAHASAN}

Penelitian ini dilakukan dengan purposive sampling, yaitu metode pemilihan sampel dengan kriteria tertentu. Berdasarkan kriteria tersebut, maka perusahaan yang memnuhi kriteria adalah 37 Perusahaan Pada penelitian ini dilakukan uji statistik deskriptif.

Tabel 2. Analisis Statistik Deskriptif

\begin{tabular}{c|c|c|c|c|c}
\hline & $\mathrm{N}$ & Minimum & Maximum & Mean & $\begin{array}{c}\text { Std. } \\
\text { Deviation }\end{array}$ \\
\hline
\end{tabular}


REVIEW OF APPLIED ACCOUNTING RESEARCH, Vol. 1, No. 1, February 2021

\begin{tabular}{l|r|r|r|r|r}
\hline $\begin{array}{l}\text { Ukuran } \\
\text { Perusahaan }\end{array}$ & 185 & 25,00 & 36,00 & 29,7027 & 1,74245 \\
\hline Audit Tenure & 185 & 1,00 & 12,00 & 3,6162 & 2,50407 \\
\hline $\begin{array}{l}\text { Audit Report } \\
\text { Lag }\end{array}$ & 185 & 22,00 & 354,00 & 88,3189 & 42,58548 \\
\hline $\begin{array}{l}\text { Valid N } \\
\text { (listwise) }\end{array}$ & 185 & & & & \\
\hline
\end{tabular}

Tabel 3. Analisis Ditribusi Frekuensi

Kualitas Audit

\begin{tabular}{l|l|r|r|r|r}
\hline \multicolumn{2}{l|}{} & Frequency & Percent & $\begin{array}{c}\text { Valid } \\
\text { Percent }\end{array}$ & $\begin{array}{c}\text { Cumulative } \\
\text { Percent }\end{array}$ \\
\hline \multirow{3}{*}{ Valid } & non big four & 99 & 53,5 & 53,5 & 53,5 \\
\cline { 2 - 6 } & big four & 86 & 46,5 & 46,5 & 100,0 \\
\cline { 2 - 6 } & Total & 185 & 100,0 & 100,0 & \\
\hline
\end{tabular}

Tabel 3. Going Concern

\begin{tabular}{l|l|r|r|r|r}
\hline \multicolumn{2}{c|}{} & Frequency & Percent & $\begin{array}{c}\text { Valid } \\
\text { Percent }\end{array}$ & $\begin{array}{c}\text { Cumulative } \\
\text { Percent }\end{array}$ \\
\hline \multirow{4}{*}{ Valid } & $\begin{array}{l}\text { non going } \\
\text { concern }\end{array}$ & 139 & 75,1 & 75,1 & 75,1 \\
\cline { 2 - 6 } & $\begin{array}{l}\text { going } \\
\text { concern }\end{array}$ & 46 & 24,9 & 24,9 & 100,0 \\
\cline { 2 - 6 } & Total & 185 & 100.0 & 100.0 & \\
\hline
\end{tabular}

Tabel 4. Analisis Regresi Logistik

Uji Keseluruhan Model (Overall Model Fit)

Hasil Pengujian Overall Model Fit

\begin{tabular}{|c|c|c|c|}
\hline \multirow{2}{*}{ Iteration } & & \multirow{2}{*}{-2 Log likelihood } & \multirow[t]{2}{*}{ Coefficients } \\
\hline & & & \\
\hline \multirow[t]{4}{*}{ Step 0} & 1 & 207,867 & $-1,005$ \\
\hline & 2 & 207,513 & $-1,103$ \\
\hline & 3 & 207,513 & $-1,106$ \\
\hline & 4 & 207,513 & $-1,106$ \\
\hline
\end{tabular}

Hasil Pengujian Overall Model Fit

\begin{tabular}{|c|c|c|c|c|c|c|c|}
\hline \multirow{2}{*}{\multicolumn{2}{|c|}{ Iteration }} & \multirow{3}{*}{$\begin{array}{r}\begin{array}{c}-2 \mathrm{Log} \\
\text { likelihood }\end{array} \\
175,960 \\
\end{array}$} & \multicolumn{5}{|c|}{ Coefficients } \\
\hline & & & \multirow{2}{*}{$\begin{array}{c}\text { Consta } \\
\text { nt } \\
-7,670\end{array}$} & \multirow{2}{*}{$\begin{array}{l}\mathrm{X} 1 \\
, 202 \\
\end{array}$} & \multirow{2}{*}{$\begin{array}{l}\mathrm{X} 2 \\
, 023 \\
\end{array}$} & \multirow{2}{*}{$\begin{array}{l}\text { X3 } \\
-, 883 \\
\end{array}$} & \multirow{2}{*}{$\begin{array}{l}\mathrm{X} 4 \\
, 011\end{array}$} \\
\hline \multirow[b]{2}{*}{ Step } & 1 & & & & & & \\
\hline & 2 & 171,430 & $-10,169$ & ,270 & ,057 & $-1,351$ & ,015 \\
\hline
\end{tabular}


1

\begin{tabular}{|l|r|r|r|r|r|r}
\hline 3 & 171,265 & $-10,671$ &, 283 &, 070 & $-1,482$ &, 015 \\
\hline 4 & 171,264 & $-10,692$ &, 284 &, 070 & $-1,489$ &, 015 \\
\hline 5 & 171,264 & $-10,692$ &, 284 &, 070 & $-1,489$ &, 015 \\
\hline
\end{tabular}

Pada tabel diatas menujukan bahwa nilai -2LogLikelihood awal block number 1 sebesar 207.867 dan nilai -2LogLikelihood akhir block number 1 sebesar 182,311. Nilai tersebut mengalami penurunan yaitu $207,867-175,960=31,907$ Hal ini berarti dapat disimpulkan bahwa hipotesis nol diterima dan model dihipotesiskan sesuai dengan data yang akan diuji atau model yang dihipotesiskan fit dengan data.

Tabel 5. Uji Kelayakan Model Regresi (Hosmer and Lemeshow's Goodness of Fit Test)

\begin{tabular}{r|r|r|r}
\hline \multicolumn{1}{c|}{ Step } & Chi-square & df & \multicolumn{1}{c}{ Sig. } \\
\hline 1 & 9,931 & & 8 \\
\hline
\end{tabular}

Tabel di atas menunjukan bahwa nilai Hosmer and Lemeshow's Goodness of Fit pada nilai Chi- Square 9,931 dengan nilai probabilitas signifikan sebesar 0,270 yang berarti nilainya > 0,05. Dapat disimpulkan bahwa model adalah fit dan dapat memprediksi variabel-variabel dalam penelitian ini, sehingga model dapat digunakan untuk analisis berikutnya

Tabel 6. Uji Koefisien

\begin{tabular}{l|r|r|r}
\hline Step & $\begin{array}{c}-2 \text { Log } \\
\text { likelihood }\end{array}$ & $\begin{array}{c}\text { Cox \& Snell R } \\
\text { Square }\end{array}$ & Nagelkerke R Square \\
\hline 1 & $171.264^{\mathrm{a}}$ &, 178 &, 264 \\
\hline
\end{tabular}

\section{Determinasi (Nilai Nagelkerke R Square)}

Tabel di atas menunjukan bahwa nilai Nagelkerke $R$ Square sebesar 0,264. Nilai tersebut dapat diartikan sebagai kemampuan variabel indpenden (ukuran perusahaan, audit tenure, kualitas audit dan audit report lag) dalam mempengaruhi variabel dependen (going concern) sebesar 26,4\% sedangkansisanya sebesar 73,6\% dijelaskan oleh variabel lain yang tidak digunakan dalam penelitian ini.

Tabel 7. Hasil Pengujian Koefisien Regresi

\begin{tabular}{l|l|r|r|r|r|r|r}
\hline \multicolumn{2}{c|}{} & \multicolumn{1}{c|}{ B } & \multicolumn{1}{c|}{ S.E. } & \multicolumn{1}{c|}{ Wald } & df & \multicolumn{1}{c}{ Sig. } & $\operatorname{Exp(B)}$ \\
\hline \multirow{3}{*}{ Step 1 $^{\text {a }}$} & X1 & 0,284 & 0,110 & 6,654 & 1 & 0,010 & 1,328 \\
\cline { 2 - 8 } & X2 & 0,070 & 0,088 & 0,634 & 1 & 0,426 & 1,073 \\
\cline { 2 - 8 } & X3 & $-1,489$ & 0,465 & 10,235 & 1 & 0,001 & 0,226 \\
\cline { 2 - 8 } & X4 & 0,015 & 0,005 & 10,680 & 1 & 0,001 & 1,016 \\
\cline { 2 - 8 } & Constant & $-10,692$ & 3,351 & 10,183 & 1 & 0,001 & 0,000 \\
\hline
\end{tabular}




\section{Pengujian Hipotesis}

H1 : Ukuran perusahaan berpengaruh negatif terhadap opini audit going concern

Hasil uji regresi logistik menunjukan bahwa signifikan ukuran perusahaan sebesar 0,010 nilai $\beta_{1}$ (ukuran perusahaan) sebesar 0,284 . Karena nilai signifikan

$>0,05$ yaitu 0,010 >0,05 dan nilai koefisien kearah positif maka $\mathrm{H}_{0}$ diterima dan $\mathrm{H}_{\mathrm{a}}$ ditolak. Dengan demikian dapat disimpulkan bahwa ukuran perusahaan tidak berpengaruh negatif terhadap opini auidit going concern. Sehingga hipotesis pertama yang menyatakan ukuran perushaan berpengaruh negatif terhadap terhadap opini audit going concern, ditolak.

H2 : Audit tenure berpengaruh negatif terhadap opini audit going concern

Hasil uji regresi logistik menunjukan bahwa signifikan audit tenure sebesar 0,426 nilai $\beta_{2}$ (audit tenure) sebesar 0,070. Karena nilai signifikan $>0,05$ yaitu 0,426 > 0,05 dan nilai koefisien kearah positif maka $\mathrm{H}_{0}$ diterima dan $\mathrm{H}_{\mathrm{a}}$ ditolak. Dengan demikian dapat disimpulkan bahwa audit tenure tidak berpengaruh negative terhadap opini audit going concern. Sehingga hipotesis kedua yang menyatakan audit tenure berpengaruh negatif terhadap opini audit going concern ditolak.

H3 : Kualitas audit berpengaruh positif terhadap opini audit going concern

Hasil uji regresi logistik menunjukan bahwa signifikan kualitas audit sebesar 0,001 nilai $\beta_{3}$ (kualitas audit) sebesar $-1,489$. Karena nilai signifikan $\leq 0,05$ yaitu 0,001 0,05 dann nilai koefisien kearah positif maka $\mathrm{H}_{\mathrm{a}}$ diterima dan $\mathrm{H}_{\mathrm{o}}$ ditolak.. Dengan demikian dapat disimpulkan bahwa kualitas audit berpengaruh positif terhadap opini audit going concern. Sehingga hipotesis kedua yang menyatakan kualitas audit berpengaruh positif terhadap opini audit going concern diterima.

H4 : Audit report lag berpengaruh positif terhadap opini audit going concern

Hasil uji regresi logistik menunjukan bahwa signifikan audit report lag sebesar 0,001 nilai $\beta_{4}$ (audit report lag) sebesar 0,015. Karena nilai signifikan $>0,05$ yaitu 0,001 0,05 dkn nilai koefisien kearah positif maka $\mathrm{H}_{0}$ ditolak dan $\mathrm{H}_{\mathrm{a}}$ diterima. Dengan demikian dapat disimpulkan audit report lag berpengaruh positif terhadapopini audit going concern. Sehingga hipotesis keempat yang menyatakan audit report lag berpengaruh positif terhadap opini audit going concern diterima

\section{PENUTUP KESIMPULAN}

Berdasarkan hasil dari regresi logistik yang dilakukan, dapt diperoleh kesimpulan sebagai berikut:

1. Ukuran perusahaan tidak berpengaruh terhadap opini audit going concern.

2. Audit tenure tidak berpengaruh terhadap opini audit going concern.

3. Kualitas audit berpengaruh positif terhadap opini audit going concern.

4. Audit report lag berpengaruh positif terhadap pemberian opini audit going concern.

\section{Keterbatasan}


Penelitian ini memiliki beberapa keterbatasan yang kemungkinan dapat mempengaruhi hasil penelitian, diantaranya adalah sebagai berikut:

1. Pemilihan objek penelitian hanya mencakup perusahaan pertambangan yang terdaftar di BEI pada tahun 2015-2019.

2. Penelitian ini hanya memiliki nilai Nagelkerke $R$ Square sebesar yang berarti $26,4 \%$ variabel going concern dapat dijelaskan oleh ukuranperusahaan, audit tenure, kualitas audit, dan audit report lag. Sedangkan sisanya sebesar 73,6\%

\section{Saran} dijelaskan oleh variabel lain yang tidak digunakan dalam penelitian ini.

Berdasarkan kesimpulan dan keterbatasan yang telah disampaikan, maka dapat diberikan saran-saran untuk penelitian selanjutnya, diantaranyasebagai berikut:

1. Penelitian selanjutnya disarankan untuk menggunakan sampel sektor perusahaan lain yang terdaftar di BEI yang lebih luas dan berbeda dengan peneltian ini.

2. Penelitian selanjutnya dapat menambah variabel independen lain yang dapat berpengaruh terhadap opini audit going concern yang dapat memprediksi pemberian opini audit going concern

\section{REFERENSI}

Andyny, R. D. (2017). Pengaruh Ukuran Perusahaan , Audit Tenure Dan Reputasi Kap Terhadap Opini Audit Going Concern Pada Perusahaan ManufakturSektor Barang Konsumsi Periode 2014-2015. Simki-Economic, 01(02), 12.

Anita, W. F. (2017). Analisis Faktor-Faktor Yang Mempengaruhi Opini Audit Going Concern Pada Perusahaan Manufaktur Yang Terdaftar Di Bursa Efek Indonesia. Jurnal Riset Keuangan Dan Akuntansi, 3(2), 87-108. https://doi.org/10.25134/jrka.v3i2.939

Chandra, I., Cianata, S., Rahmi, N. U., Zai, F. S., Alvina, A., \& Batubara, M. (2019). Pengaruh Kualitas Audit, Debt Default (Kegagalan Hutang) dan Ukuran Perusahaan terhadap Penerimaan Opini Audit Going Concern pada Subsektor Perusahaan Tekstil \& Garment Yang Terdaftar Di Bursa Efek Indonesia pada Periode 2014-2017. Owner, 3(2), 289. https://doi.org/10.33395/owner.v3i2.124

Fahmi, M. N. (2016). Pengaruh Audit Tenure, Opini Audit Tahun Sebelumnya, Dan Disclosure Terhadap Opini Audit Going Concern. Akuntabilitas, 8(3), 162-170. https://doi.org/10.15408/akt.v8i3.2770

Hamdani, D. (2019). Pengaruh Tenure Audit, Tingkat Pertumbuhan Perusahaan, Ukuran KAP, Ukuran Perusahaan Dan Financial Distress Terhadap Auditor Switching. 18(2), 15-29.

Harjito, Y. (2017). Analisiskecenderungan Penerimaan Opini Audit Going Concern Pada $\begin{array}{llll}\text { Perusahaan } & \text { Manufaktur. Jurnal } & \end{array}$ https://doi.org/10.24912/ja.v19i1.112 
Hati, I. P., \& Rosini, I. (2017). Pengaruh Opini Audit Tahun Sebelumnya dan Kondisi Keuangan terhadap Opini Audit Going Concern. Journal of Applied Accounting and Taxation, 2(2), 123-133.

Istiana, S. (2010). Pengaruh Kualitas Audit, Opinion Shopping, Debt Default Pertumbuhan Perusahaan Dan Kondisi Keuangan Perusahaan Terhadap Penerimaan Opini Audit G O I N G C O N C E R N. Jurnal Akuntansi \& Investasi, 11(1), 80-96.

Kartika, A., Studi, P., Universitas, A., Kendeng, S. J., Bendan, V., \& Semarang,

N. (2012). PENGARUH KONDISI KEUANGAN DAN NON KEUANGAN TERHADAP PENERIMAAN OPINI GOING CONCERN PADA PERUSAHAAN MANUFAKTUR DI BEI The Effect of Financial Condition and Non Financial of Going Concern in the Manufacturing Companies Listed at Indonesia Stock Exchange. 1(1), 25-40.

Kusumaningrum, Y. (2019). Analisis Pengaruh Ukuran Perusahaan, Likuiditas Dan Leverage Terhadap Penerimaan Opini Audit Going Concern. Diponegoro Journal of Accounting, 8(4), 1-12.

Melania, Sutra; Andini, Rita; Arifati, R. (2019). Analisis Pengaruh Kualitas Auditor, Likuiditas, Profitabilitas, Solvabilitas dan Ukuran Perusahaan terhadap Opini Audit Going Concern pada Perusahaan Manufaktur yangTerdaftar di Bursa Efek Indonesia. Journal of Chemical Information and Modeling, 53(9), 1689-1699.

Minerva, L., Sumeisey, V. S., Stefani, S., Wijaya, S., \& Lim, C. A. (2020). Pengaruh Kualitas Audit, Debt Ratio, Ukuran Perusahaan dan Audit Lag terhadap Opini Audit Going Concern. Owner, 4(1), 254. https://doi.org/10.33395/owner.v4i1.180

Mutsanna, H., \& Sukirno, S. (2020). Faktor Determinan Opini Audit Going Concern Pada Perusahaan Manufaktur Yang Terdaftar Di Bursa Efek Indonesia Tahun 2016-2018. Nominal: Barometer Riset Akuntansi Dan Manajemen, 9(2), 112-131. https://doi.org/10.21831/nominal.v9i2.31600

Oktaviani, \& E, A. (2020). Pengaruh Kualitas Auditor, Audit Tenure Dan Debt Default Terhadap Penerimaan Opini Audit Going Concern. Akuntansi Dan Keuangan, 8.

Qolillah, S. (2016). Analisis yang Memengaruhi Opini Audit Going Concern pada Perusahaan Manufaktur yang Terdaftar di Bursa Efek Indonesia. Journal Riset Mahasiswa, 4(1), 1-10.

Sari, P. C. (2020). Pengaruh Audit Lag, Profitabilitas Dan Likuiditas Terhadap Opini Audit Going Concern Pada Perusahaan Manufaktur Yang Terdaftar Di Bursa Efek Indonesia. Jurnal Riset Akuntansi Warmadewa, 1(1), 1-7. https://doi.org/10.22225/jraw.1.1.1509.1-7

Sufiana, \& Karina, R. (2020). Pengaruh efektivitas komite audit, kualitas audit dan efektivitas dewan direksi terhadap manajemen laba. Journal of Applied Managerial Accounting, 4(1), 42-59.

RAAR

Vol.1 No.1
Syahputra, F., \& Yahya, M. R. (2017). Pengaruh Audit Tenure, Audit Delay,Opini Audit Tahun Sebelumnya dan Opinion Shopping Terhadap Penerimaan Opini Audit Going Concern pada Perusahaan Manufaktur yang Terdaftar di Bursa Efek Indonesia 
Tahun 2013-2015. Jurnal IlmiahMahasiswa Ekonomi Akuntansi (JIMEKA), 2(3), 29.

Vernando, A., \& Yuniarto, A. S. (2018). Faktor-Faktor Yang Mempengaruhi Penerimaan

Opini Audit Going Concern. Jurnal REKSA: Rekayasa Keuangan, Syariah Dan Audit, 3(2), 129.

https://doi.org/10.12928/j.reksa.v3i2.31

Yanuariska, M. D., \& Ardiati, A. Y. (2018). Pengaruh Kondisi Keuangan, Audit Tenure, dan Ukuran KAP terhadap Opini Audit Going Concern pada Perusahaan Manufaktur yang Terdaftar di BEI Tahun 2012-2016. Jurnal Maksipreneur: Manajemen, Koperasi, Dan Entrepreneurship, 7(2), 117. https://doi.org/10.30588/jmp.v7i2.361 